\title{
Growth curve of Nellore calves reared on natural pasture in the Pantanal
}

\author{
Sandra Aparecida Santos ${ }^{1}$, Geraldo Silva e Souza ${ }^{2}$, Ciniro Costa ${ }^{3}$, Urbano Gomes Pinto de \\ Abreu $^{1}$, Fabiana Villa Alves ${ }^{4}$, Luís Carlos Vinhas Ítavo ${ }^{5}$
}

\footnotetext{
1 Embrapa Pantanal, CP 109, 79320-900, Corumbá, MS.

2 Embrapa/SEA, 70770-901, Brasília, DF.

3 FMVZ- UNESP Campus de Botucatu, CP 560, 18618-000, Botucatu, SP.

${ }^{4}$ Embrapa Gado de Corte, CP 154, 79002-970, Campo Grande, MS.

5 Universidade Católica Dom Bosco - UCDB, 79117-900, Campo Grande, MS.
}

\begin{abstract}
Weight-age and hip height-age relations of Nellore calves, from birth to 10 months old were fitted using a logistic model including sex and year of birth as fixed effects. Calves and their dams were reared on natural pasture using continuous grazing system. The crude protein content and total digestible nutrients were analyzed for pasture selected by the animals. The weights of the calves were adjusted to 205 days and 365 days. There were no significant effects of sex and birth year on the growth curve parameters, but there were significant effects of sex on hip height. The average weight ( $a$ parameter) at 10 months of age was $170 \mathrm{~kg}$ and the inflection point was observed at 93.5 days old. When weight-age and hip height-age curves were combined in the same graph, the intersection occurred at 142 days. The number of days to gain $160 \mathrm{~kg}$ from birth to 205 days of age (adjusted) and number of days to gain $240 \mathrm{~kg}$ from 205 days to slaughter was different between the birth years, which were probably due to the quality of the natural pastures. It is necessary to implement nutritional management strategies such as high quality pasture and/or feeding supplementation for calves once they reach three months of age.
\end{abstract}

Key Words: beef cattle, hip height, weanling weight

\section{Introduction}

Sustainable management of natural areas rich in biodiversity such as the Pantanal is a pressing need. It is essential to consider the natural resources and ecological processes involved (animal-plant-soil relationship and other environmental components), aiming towards ecosystem ecological balance (Santos et al., 2008).

Developed for more than 200 years in the Pantanal, beef cattle ranching is part of this ecosystem. It constitutes the main economic activity of the region where the calves are the main product (Abreu et al., 2000). However, in recent years, Pantanal ranches have suffered a decrease in carrying capacity due to several factors, such as marital share and increase in invasive species on pastures. In search for technological alternatives to increase the cattle productivity in a sustainable way, consonant to world growth by natural products, a program was instituted as 'Pantanal's organic veal' - VITPAN (Mato Grosso do Sul, 2000), aiming to give conditions to aggregate values to calf production. However, this program has not yet reached the success desired in the region, mainly due to lack of basic knowledge and technologies being applied to nutritional management of calves and the development of more precocious lineages or breeds adapted to local climatic conditions (Santos et al., 2008).
In this scenario, one of the fundamental studies would be the definition of the growth curve of calves reared on natural pastures, because it would allow the potential of the animals reared in these conditions to be verified. If so, studies on calf growth can provide subsidies to define selection criteria for growth and sexual precocity (Garnero et al., 2001) in function of characteristics inherent to breed and to assist nutritional management of the animals as well.

This study aimed to fit growth curves of Nellore calves from birth to natural weaning, reared exclusively on natural pastures with the objective to develop management strategies to improve calves performance in the Pantanal.

\section{Material and Methods}

This research was conducted in an area of 151 ha, representative of the Nhecolândia sub-region, Pantanal (lat. $19^{\circ} 04^{\prime}$ S, long. $5636^{\prime} \mathrm{W}$, alt. 98m), between October 1997 and September 1999, comprising two hydrological years (1997/98 and 1998/99). The annual precipitation was $1125.7 \mathrm{~mm}$ and $895.9 \mathrm{~mm}$ for $1997 / 98$ and 1998/99, respectively (Figure 1 ).

The study area contains diverse landscape units (physiognomies): a) semideciduous forest, regionally known as 'mata'; b) forested savanna, known as ‘cerradão'; 


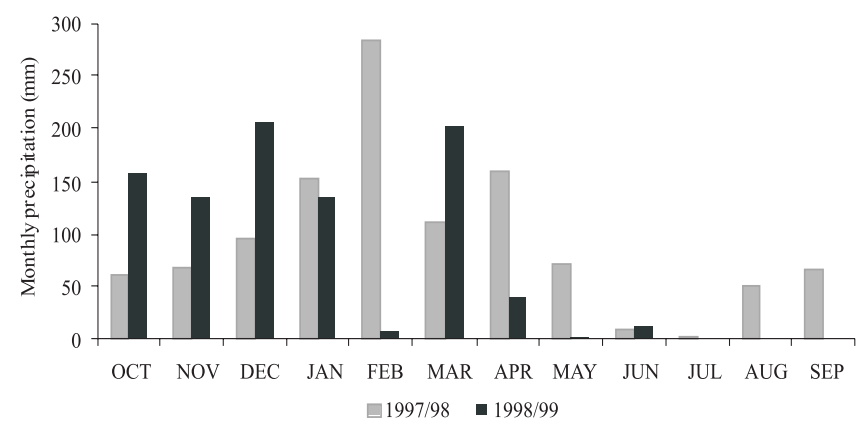

Figure 1 - Monthly precipitation data for the years 1997/98 and 1998/99 (Estação Climatologica de Nhumirim, Pantanal).

c) arboreal savanna, known as 'campo cerrado'; d) open grasslands with predominance of Axonopus purpusii and Andropogon spp., known as 'campo limpo'; e) opengrassland with predominance of Elyonurus muticus, known as 'caronal'; f) permanent ponds, known as 'baías'; g) temporary ponds which can dry up in some seasons of the year; and h) temporary canals and lowlands. From these landscapes units only 'mata', 'cerradão', 'campo cerrado' and 'caronal' do not suffer periodic flooding.

Forty-six Nellore cows were continuously grazed at light stocking rate of $3.3 \mathrm{ha} / \mathrm{cow}$ to allow ample opportunity for selective grazing. General management of the animals followed the outline adopted by the Nhumirim farm (Embrapa, 1997), with the natural breeding season from December to February and ratio of females to males equal to $25: 1$. The two male breeders were the same during the two years of study. A total of 10 cows with calf at foot were selected from the herd in 1997 and 1998, based on their date of birth. Calves were weighed monthly after fasting for approximately 12 hours and measured for hip height until they were self-weaned at 10-11 months. However, two calves were weaned earlier because their mothers were in poor body condition.

The weight-age and hip height-age relationships were analyzed using the following logistic model (Ratkowsky, 1983):

Weight or hip height $=\mathrm{a} /\left(1+\mathrm{b}^{*} \exp \left(-\mathrm{c}^{*}\right.\right.$ age $\left.)\right)$,

where: $a$ represents the average size at 10-11 months; $b$ is a constant of integration and; $c$ refers to mean slope of a nonlinear equation, indicating growth rate related to adult size.

The NLIN procedure in SAS (2001) using the GaussNewton method for ordinary least square was adopted to fit and estimate the parameters of the nonlinear function.

For age: weight curve, the inflection point was estimated by $-\log (b) / c$, where $\log$ is natural $\log$.
The parameters of function were analyzed using the following model:

$\mathrm{Y}_{\mathrm{ij}}=\mu+\mathrm{A}_{\mathrm{i}}+\mathrm{S}_{\mathrm{j}}+\mathrm{E}_{\mathrm{ij}}$, where: $\mu$ = overall mean; $A_{i}=$ effect of $i^{\text {th }}$ year; $S_{j}=$ effect of sex; $E_{i j}=$ random error.

The confidence intervals follow the methods of simultaneous regions described by Souza (1998) and Bates \& Watts (1988).

The sites that were more intensively used for foraging within the utilization area were identified during the main grazing period in the late afternoon to assess the quality of the pastures. In these areas, 30 quadrats were allocated $(0.25 \times 0.25 \mathrm{~m})$, of which 15 were cut at ground level and 15 to simulate grazing by cattle. All samples were dried at $65^{\circ} \mathrm{C}$ and analyzed for crude protein (CP) using the Kjedhal method adapted by Galvani \& Gaertner (2006), and acid detergent fiber (ADF), according to Van Soest et al. (1991). Total digestible nutrients (TDN) was calculated by TDN $=[88.9-(0.779 \times \mathrm{ADF} \%)]($ Rohweder et al., 1978) and TDN:CP ratio were estimated for the diet that was selected monthly.

The weight of the calves was adjusted to a 205-day basis (P205) and 365-day basis (P365), according to Rosa (1997). P205 age is usually adopted for weanling in the region. Average daily gain (ADG) values from birth to 205 days of age (ADG205) and from 205 days to 365 of age (ADG365) of pre-corrected weights were used to calculate the number of days to gain $160 \mathrm{~kg}$ from birth to 205 days of age (D160), and number of days to gain $240 \mathrm{~kg}$ from 205 days of age until slaughter (D240), according to respective equations D160 = 160/ADG205 and D240 = 240/ADG365 (Fries et al., 1996).

\section{Results and Discussion}

Weight trait was not influenced by year and sex variables or by the interaction between them, with a significant effect only for the sex variable on the hip height trait (Table 1). Thus, for the weight trait, one curve for both sexes was fitted (Figure 2), while for the hip height trait two curves were required, one for males (Figure 3) and another for females (Figure 4).

The asymptotic $a$ of the fitted function represents the potential size of the Nellore calves at about 10 months of age that were reared on natural pastures and suckling. The average values obtained were $143.08 \mathrm{~kg}$ and $131.15 \mathrm{~cm}$ for weight and hip height, respectively.

Parameter $b$ is an integration constant that adjusts birth weight values. Parameter $c$, normally referred to as maturing rate, relates to growth rate associated to body size. This 
Table 1 - Variance analysis summary of parameters of the logistic model $^{1}$ for weight and hip height of Nellore calves from birth until 10 months of age, reared in natural pastures in the Pantanal

\begin{tabular}{lccc}
\hline & \multicolumn{3}{c}{ Computed F value } \\
\cline { 2 - 4 } Weight & $a$ & $b$ & $c$ \\
\hline Year & $1.43 \mathrm{~ns}$ & $0.59 \mathrm{~ns}$ & $0.84 \mathrm{~ns}$ \\
Sex & $0.49 \mathrm{~ns}$ & $1.46 \mathrm{~ns}$ & $0.14 \mathrm{~ns}$ \\
Year*sex & $0.29 \mathrm{~ns}$ & $0.21 \mathrm{~ns}$ & $0.16 \mathrm{~ns}$
\end{tabular}

Hip height

\begin{tabular}{lccc} 
& $a$ & $b$ & $c$ \\
Year & $1.41 \mathrm{~ns}$ & $0.17 \mathrm{~ns}$ & $1.42 \mathrm{~ns}$ \\
Sex & $4.87^{*}$ & $2.06 \mathrm{~ns}$ & $6.76^{*}$ \\
Year*sex & $0.03 \mathrm{~ns}$ & $2.14 \mathrm{~ns}$ & $4.29 \mathrm{~ns}$ \\
\hline
\end{tabular}

${ }^{1}$ Model: Weight or hip height $=a /\left(1+b^{*} \exp \left(-c^{*}\right.\right.$ age $\left.)\right)+$ error. $\mathrm{ns}=$ not significant; $*(\mathrm{P}<0.05)$.

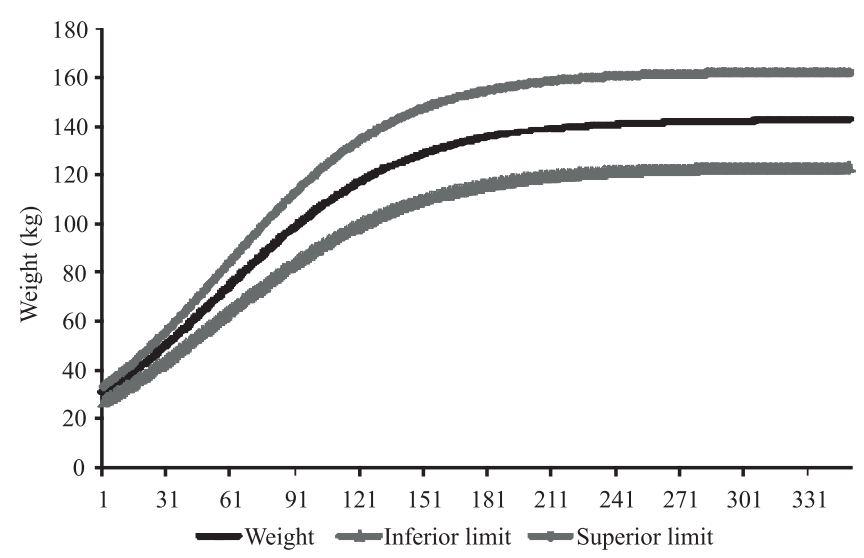

Figure 2 - Weight growth curve and respective confidence intervals (inferior and superior limits) as a function of age of Nellore calves reared on natural pastures in the Nhecolândia sub-region, Pantanal.

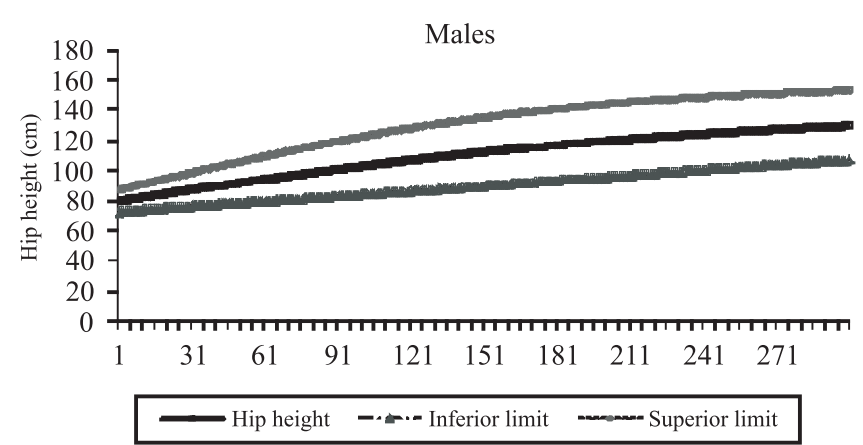

Figure 3 - Hip height growth curve and respective confidence intervals as a function of age of Nellore male calves reared on natural pastures in the Nhecolândia subregion, Pantanal. value allows an estimation of the precocious maturity. In this study, the values obtained were $-0.023 \mathrm{~kg}$ and $-0.011 \mathrm{~cm}$ for weight and hip height respectively. According to Brody (1945), the values $a$ and $c$ are intrinsic ontogenetic characteristics of the animals expressed under specific environmental conditions.

In relation to weight, the average inflection point was 93.5 days. At this point, the growth rate declined, probably due to decreased milk supply of the cows (Oliveira et al., 2007). In comparison, when weight and hip height curves were plotted on the same graph, where the estimated age at the point of intersection was 142 days (Figure 5).

Trenkle \& Marple (1983) reported that during the early stage of postnatal growth a rapid growth with great changes, mainly in the skeletal system, happens until the animal reaches approximately $50 \%$ to $60 \%$ of its mature weight. However, some scientists have ignored this fact, paying

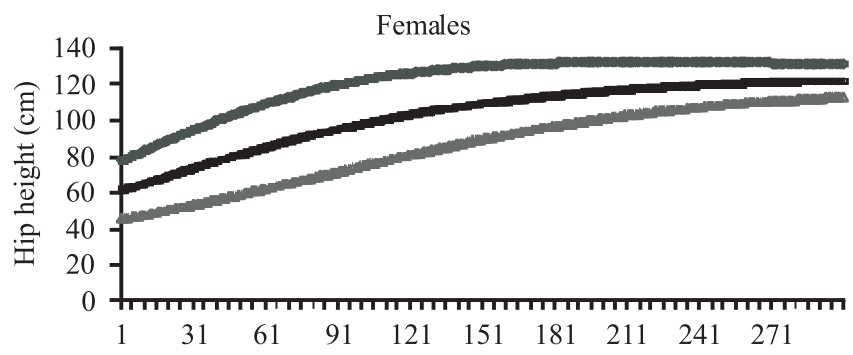

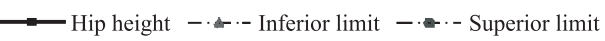

Figure 4 - Hip height growth curve and respective confidence intervals as a function of age of Nellore female calves reared on natural pastures in the Nhecolândia subregion, Pantanal.

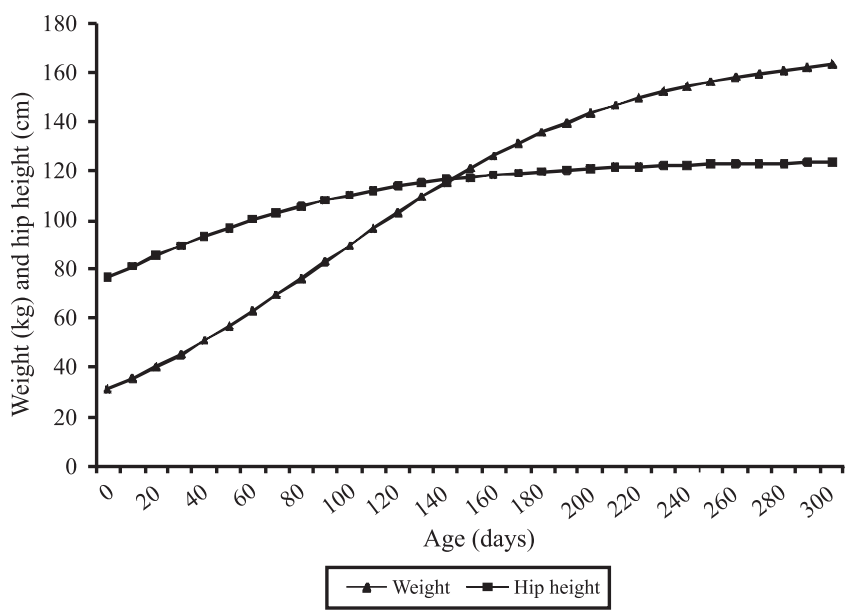

Figure 5 - Weight and hip height curves of Nellore calves, from birth to 300 days of age, reared in natural pasture, in the Nhecolândia sub-region, Pantanal. 
more attention to muscle growth (weight gain) and fat deposition. Havstad et al. (1989) evaluated the growth pattern, from birth to weaning of spring-born calves in a temperate climate region. They verified that the highest growth rate occurs in the period from 120 to 160 days, results similar to the present study. Therefore, in the first five months, the growth rate of calves in weight and hip height start to decrease. This justifies the precocious weanling and the inclusion of feeding supplementation by creep feeding. However, some studies have shown the importance of giving feeding concentrate during the first month in order to promote volatile fatty acid production, particularly butyric and propionic acid, responsible for the development of rumen papillae. This enables an increased intake capacity and digestion/fermentation of solid foods (pastures) and, thus, improved performance/weight gain in calves (Anderson et al., 1987; Nussio et al., 2003; Ítavo et al., 2007).

Growth rate is influenced by several factors, including nutrition. Nutrients are generally utilized in the hierarchical order of maintenance, growth, reproduction, lactation and slaughter. The priority for partioning the nutrients is influenced in part by the genetics of the animal (Noller, 1997). Therefore, each tissue presents greater gain rates at different times, with the deceleration in the growth following the same hierarchical order (Grant \& Helferich, 1991). As the calves of this study were kept exclusively on pastures, their nutrition depended mainly on maternal ability and pasture conditions, subject to variations in the quality as a function of available forage species. In the Pantanal, besides seasonal variation, there are annual variations dependent on the level and rainfall distribution which may or may not flood the lower areas. According to Santos et al. (2002), these lower areas are preferred by cattle for grazing because they have a better quality of forage species. As stated by Comastri Filho (1984), 'relative abundance'of the pastures is observed, in general, from October to December (during the rainy season) and from April to June (the end of the flooding period). According to the same authors, the forage availability varies as a function of the flooding regime from January to April, while from July to September overgrazing happens on lower areas.

In the Pantanal and other tropical regions calves are usually weaned at seven months; however, in this study, calves were kept with their mother until 10 months of age in order to accomplish growth and natural weanling, which is one of the criteria for the organic production system. Live weights (LW), adjusted to 205 days, were $135.5 \mathrm{~kg}$ and $149.5 \mathrm{~kg}$ for 1997/98 and 1998/99, respectively, which are both close to $145 \mathrm{~kg}$, an average found by Afonso et al. (2001) for Nellore calves weaned at seven months of age during four consecutive years (1994-1999), in the same sub-region. However, Santos et al. (2004) found lower values in extremely dry years for Nellore calves at 12 months of age, with an average weight estimated at $146 \mathrm{~kg}$. Nevertheless, Itavo et al. (2008), studied the slaughter weight of Nellore calves weaned to 8,9 and 10 months of age, and observed average of $181.5 \mathrm{~kg} \mathrm{LW}$ for animals reared in cultivated pasture. The authors attributed this satisfactory performance to the diversity of the pasture and possibility of diet selection. Another factor may have been the selection of better calves for veal production. By comparing calves weights on mixed pasture (natural and cultivated) versus cultivated pastures, the averages were 213.3 and $191.6 \mathrm{~kg}$ for calves of 8 and 10 months of age, respectively. According to Rosa (1997), weanling weight is one criterion used to evaluate the maternal ability of cows, where calves with low performance can be discarded.

During the study period, natural pasture presented higher crude protein content from October to December for both years (Figure 6). Although there was no significant difference in the growth parameters of weight between years, the W205 (weaning) of calves born in 1998 was higher than for calves born in 1997 (Table 2), probably due to better pasture quality. But, it was noted that the weight gain from May (the period usually adopted for weanling in the region calves about seven months old) had greater influence on animal growth rate, thus, on potential mature size. This period corresponds to the beginning of the feeding restriction period in the Pantanal (Santos et al. 2002).

The dietary ratio of TDN to CP (TDN:CP) is one of the criteria used to evaluate cattle nutrition. This ratio should be kept close to seven in order to get some degree of balance in the intake of protein and energy (Moore \& Kunkle, 1998). In this study, the forage selected by cattle represented a ratio close to seven, but variable between the years (Figure 6).

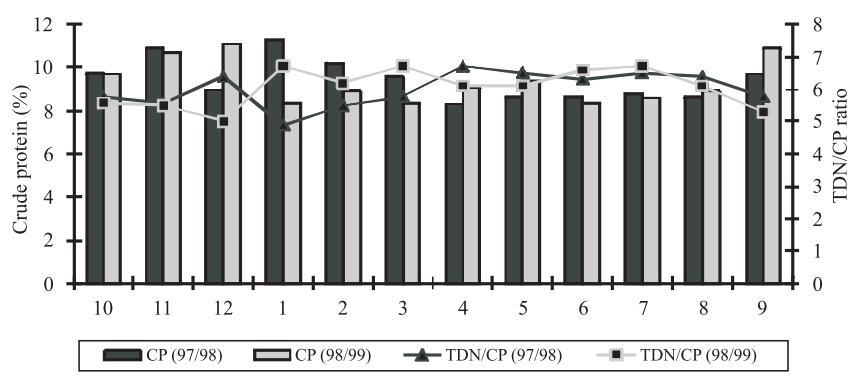

Figure 6 - Crude protein (CP) levels and total digestible nutrients (TDN) and TDN:CP ratio of the diet selected by cattle in natural pastures during the hydrological years of 1997-1998 and 1998-1999, in the Nhecolândia subregion, Pantanal. 
Table 2 - Means and standard deviation for weight and average daily gain traits for calves born in the hydrological years 1997/98 and 1998/99, in the Nhumirim ranch, Nhecolândia sub-region, Pantanal

\begin{tabular}{lcc}
\hline & years $1997 / 98$ & years $1998 / 99$ \\
\hline BW $^{1}$ & $29.1 \pm 2.1$ & $29.3 \pm 0.7$ \\
W205 $^{2}$ & $135.5 \pm 19.2$ & $149.5 \pm 19.8$ \\
$\mathrm{ADG}_{205}$ & $0.53 \pm 0.10$ & $0.59 \pm 0.11$ \\
$\mathrm{D} 160^{4}$ & 302 & 271 \\
$\mathrm{~W}^{3} 65^{5}$ & $184.3 \pm 30.1$ & $171.9 \pm 19.8$ \\
$\mathrm{ADG}^{5}$ & $0.24 \pm 0.10$ & $0.11 \pm 0.05$ \\
$\mathrm{D} 245^{7}$ & 1000 & 2180 \\
\hline
\end{tabular}

${ }^{1} \mathrm{BW}$ - birth weight (kg); ${ }^{2} \mathrm{~W} 205$ - weights adjusted to 205 days of age $(\mathrm{kg})$; ${ }^{3}$ ADG205 - average daily gain from birth to 205 days of age $(\mathrm{kg}) ;{ }^{4} \mathrm{D} 160$ - number of days to gain $160 \mathrm{~kg}$ from birth to 205 days of age; ${ }^{5} \mathrm{~W} 365$ - weights adjusted to 365 days of age; ${ }^{6} \mathrm{ADG} 365$ - average daily gain from 205 to 365 days of age (kg); ${ }^{7} \mathrm{D} 240$ - number of days to gain $240 \mathrm{~kg}$ from 205 days until slaughter.

In general, the TDN:CP ratio was maintained below seven, indicating probable balance between TDN and CP (Moore \& Kunkle, 1998). However, low pasture availability can explain the need for provision of multiple supplements (energy-protein-mineral) in creep feeding in order to complement the diet in this management system. Nutrient deficiencies, TDN and CP, or both, can limit the performance of grazing animals because the cow may not be able to meet the maintenance and growth requirements of their calves for more than 60 days after calving (Ensminger et al., 1990).

During the hydrological years 1997/98, Catto \& Afonso (2001) observed an average weight of $140.6 \mathrm{~kg}$ for Nellore calves weaned at around eight months in the Pantanal; values similar to those in the present study. These results can be compared, as they have been obtained during the same hydrological year and in the same sub-region. Except for feeding supplementation, calves had similar management in relation to stocking rate and general management. These authors also verified that the use of feeding supplementation for calves during a restricted period, June to October, allowing better utilization of natural pasture and, thus, major weight gain.

Bailey et al. (1975) verified that Hereford calves reared on natural pasture in Australia and weaned at 10 months old could probably be heavier than calves weaned at eight months old. Moreover, if calves weaned at 8 months receive balanced nutrition, either in the form of quality forage or hay, they can gain more weight than staying with the mother.

Several studies conducted in the Pantanal (Tullio et al., 1980; Almeida et al., 1994; Catto \& Afonso, 2001) have shown that the increase of the calving interval is related to weanling age. This fact is well known because during the lactating period, the nutritional needs of cows increase. If the diet does not supply these requirements, reproduction can be impaired (Gottschall \& Lobato, 1996; Catto \& Afonso, 2001).
Abreu et al. (2000), evaluating the reconception rate of Nellore cows, verified that the reconception frequency is associated with cows' sexual maturity and calving time. Cows that calved earlier (beginning of plant growth season) had more facility to calve in the following year. This is due to a period of greater availability of better quality of pasture for cows that calve earlier. According to Noller (1997), energy deficit is probably one of the main factors that influence reproduction, although protein, minerals and vitamin deficits are also involved. However, according to the same author, subnutrition has been associated with low serum progesterone levels as well as higher conception rates when the cow gained or maintained weight. Hence, body condition score of cows could be important to evaluate the metabolic activity capacity after calving. This is in agreement with studies of Santos et al. (2009). In this experiment, cows showed body condition scores above five (on a scale from 1 to 9 ) during the pre-mating period and lactation in the year 1998/99, which reflected in one higher birth rate (82\%) in the following year, 1999/2000 (Santos et al., 2002).

As the average daily gain is not linear, the weight of calves were adjusted to standard ages. Calves born in 1988 had greater W205 than calves born in 1997; however, the reverse was observed for W365 (Table 2). Feeding quality during growth is important in expressing their genetic potential. During the year 1998/99, two factors probably contributed to decrease the quality of the pasture: partial flooding (decreasing the areas preferred for grazing), and irregular rainfall distribution (causing a marked feeding restriction period). Another probable factor could have been compensatory growth but, according to Poppi and McLennan (1995), this growth occurs mainly during the rainy period (plant growth), after a feeding restriction period. The lower pre-weaning weight gain of calves born in 1997/98 could have been attributed to a lower milk consumption that was due to a probable lower crude protein level selected by cows on pasture (Figure 6). Under these conditions, calves could have consumed more pasture. According to Ansotegui et al. (1991), calves start to graze at around 45 days old, becoming self-sufficient at 70-100 days old. However, this animal category is less efficient in the consumption considered 'adequate', because they even present exploratory grazing behaviour, decreasing performance in situations of feeding restriction. For Berge (1991), animals that suffer feeding restriction during the milking phase take more time to compensate weight gain, a fact that is not observed in this study (Table 2).

The use of breeds and/or biotypes adapted to local environment conditions associated with the optimization of forage resources are essential to assure the sustainability 
of production systems, based exclusively on pastures (Santos et al., 2006). Thus, in a breeding system on natural pastures, such as the Pantanal, the smaller cows generally are more productive. This happens because they are nutritionally less exigent. However, ideal calves may have traits such as higher weight gain rate. In general, during the post weanling period calves are reared until slaughter on pastures of the plateau (Catto \& Comastri Filho, 2003). Within the Nellore breed, there are possibilities to select more efficient animals, i.e., animals that manifest lower exigency levels for maintenance energy (DiCostanzo et al., 1991). Thus, studies need to be intensified in order to evaluate adaptive characteristics of cattle, for each environment associated with the product trait required by market. Market niches also have to be searched to aggregate product value, originating from an environmentally-friendly production system.

\section{Conclusions}

Nellore calves reared on natural pasture in the Nhecolândia sub-region, Pantanal, with natural weanling showed an average weight potential of $170 \mathrm{~kg}$ at 10 months of age. In this sub-region, it seems appropriate to start the adoption of nutritional management in calves once they reach three months old. This can be achieved as a combination of supplementation in creep feeding and providing better quality pastures.

\section{Acknowledgements}

We thank Kerry Pearn, Marçal Henrique Amici Jorge and $\mathrm{M}$. Elisabeth Peters for reading and reviewing the manuscript and providing helpful suggestions. We also acknowledge the anonymous reviewers for their valuable contributions to this manuscript.

\section{References}

ABREU, U.G.P.; CHALITA, L.V.A.S.; MORAES, A.S. et al. Introdução de tecnologias no sistema de produção de bovinos de corte no Pantanal, sub-região da Nhecolândia, MS. Corumbá: Embrapa Pantanal, 2000. 37p. (Circular Técnica, 25).

AFONSO, E.; CATTO, J.B.; POTT, E.B. et al. Suplementação mineral para vacas de cria no Pantanal Mato-Grossense. Corumbá: Embrapa Pantanal, 2001. 6p. (Embrapa Pantanal. Comunicado Técnico, 25).

ALMEIDA, I.L. de; BRUM, P.A.R. de; TULLIO, R.R. et al. Desempenho reprodutivo de bovinos na sub-região dos Paiaguás do Pantanal Mato-Grossense: III efeito da idade de desmama em vacas de cria. Pesquisa Agropecuária Brasileira, v.29, n.3, p.461-465, 1994.

ANDERSON, K.L.; NAGARAJA, T. G.; MORRILL, J. L. Ruminal metabolic development calves weaned conventionally or early. Journal of Dairy Science, v.70, p.1000-1005, 1987.
ANSOTEGUI, R.P., HAVSTAD, K.M., WALLACE, J.D. et al. Effects of milk intake on forage intake and performance of suckling range calves. Journal of Animal Science, v.69, p.899-904, 1991.

BAILEY, P.J.; HALLS, M.A.; BISHOP, A.H. Effect of weaning age and post-weaning nutrition on the growth of calves and the live weight of their dams. Australian Journal of Experimental Agriculture and Animal Husbandry, v.15, n.76, p.581-586, 1975.

BATES, D.M.; WATTS, D.G. Nonlinear regression analysis and its applications. New York: John Willey, 1988. 365p.

BERGE, P. Long-term effects of feeding during calf hood on subsequent performance in beef cattle (a review). Livestock Production Science, v.28, p.179-201, 1991.

BRASIL. Portaria $\mathrm{n}^{0}$ 612, de 5 de outubro de 1989. Dispõe sobre a tipificação das carcaças bovinas. Diário Oficial, Brasília, 6 outubro 1989.

BRODY, S. Bioenergetics and growth. New York: Reinhold Publishing Corp, 1945. 1023p.

CATTO, J.B.; AFONSO, E. Taxa de natalidade de vacas e desempenho de bezerros sob desmama antecipada no Pantanal. Pesquisa Agropecuária Brasileira, v.36, n.9, p.1205-1211, 2001.

CATTO, J.B.; COMASTRI FILHO, J.A. Taxa de natalidade no rebanho bovino no Pantanal: nutrição, sanidade e genética. Corumbá: Embrapa Pantanal, 2003. 8p. (Comunicado Técnico, 29).

COMASTRI FILHO, J.A. Pastagens nativas e cultivadas no Pantanal Mato-grossense. Corumbá: EMBRAPA-CPAP, 1984. 48p. (Circular Técnica, 13).

DICOSTANZO, A.; MEISKE, J.C.; PLEGGE, S.D. Characterization of energetically efficient and inefficient beef cows. Journal Animal Science, v.69, p.1337-1348, 1991

EMPRESA BRASILEIRA DE PESQUISA E AGROPECUÁRIA EMBRAPA. Centro de Pesquisa Agropecuária do Pantanal (Corumbá-MS). Plano de utilização da fazenda Nhumirim. Corumbá: EMBRAPA- CPAP, 1997.

ENSMINGER, M.E.; OLDFIELD, J.E.; HEINEMANN, W.W. Feeds and nutrition. 2.ed. Clovis: The Ensminger Publishing, 1990. 1544p.

FrieS, L.A; BRITO, F.V.; AlbuQUerque, L.G. Possíveis conseqüências de seleção para incrementar pesos às idadespadrão vs. Reduzir idades para produzir unidades de mercado. In: REUNIÃO ANUAL DA SOCIEDADE BRASILEIRA DE ZOOTECNIA, 33., 1996, Fortaleza. Anais... Fortaleza: SBZ, 1996. p.310-312.

GARNERO, A.V.; LÔBO, R.B.; BEZERRA, L.A.F. et al. Comparação entre alguns critérios de seleção para crescimento na raça Nelore. Revista Brasileira de Zootecnia, v.30, n.2, p.714-718, 2001.

GALVANI, F.; GAERTNER, E. Adequação da metodologia Kjeldah para determinação de nitrogênio total e proteína bruta Corumbá: Embrapa Pantanal, 2006. 9p. (Circular Técnica, 63).

GOTTSCHALL, C.S.; LOBATO, J.F.P. Comportamento reprodutivo de vacas de corte primíparas submetidas a três lotações em campo nativo. Revista Brasileira de Zootecnia, v.25, n.1, p.46-57, 1996

GRANT, A.L.; HELFERICH, W.G. An overview of growth. In: PERSON, A.M.; DUTSON, T.R. (Eds.). Growth regulat on in farm animals: advances in meat research. New York: Elsevier Science Publishing Co., 1991. v.7, p.1-16.

HAVSTAD, K.M.; McNERNEY, M.J.; CHURCH, S.B. Growth patterns of range beef calves over discrete pre-weaning intervals. Canadian Journal of Animal Science, v.69, p.865-869, 1989.

ÍTAVO, L.C.V.; OLIVEIRA, N.P.R.; ÍTAVO, C.C.F. et al. Produção de bezerros jovens em pastagens nativas, mistas ou cultivadas no Pantanal Sul-Mato-Grossense. Revista Brasileira de Saúde e Produção Animal, v.9, n.3, p.585-593, 2008.

ÍTAVO, L.C.V.; ÍTAVO, C.C.B.F.; SOUZA, S.R.M.B.O. et al Avaliação da produção de bezerros em confinamento ou em suplementação exclusiva. Arquivo Brasileiro de Medicina Veterinária e Zootecnia, v.59, n.4, p.948-954, 2007. 
MATO GROSSO DO SUL. Secretaria de Estado de Produção. Projeto de apoio à criação do Parque Natural Regional do Pantanal. Programa Vitelo do Pantanal. Campo Grande: SEPRODES, 2000. 45p.

MOORE, J.E.; KUNKLE, W.E. Balancing protein and energy in forages. In: FLORIDA BEEF CATTLE SHORT COURSE, 1998, Gainesville. Proceedings... Gainesville: University of Florida, 1998. p.119-126.

NOLLER, C. R. Nutritional requirements of the grazing animal. In: SIMPÓSIO INTERNACIONAL SOBRE PRODUÇÃO ANIMAL EM PASTEJO, 1., 1997, Viçosa, MG. Anais... Viçosa, MG: UFV, 1997. p.145-172.

NUSSIO, C.M.B.; SANTOS, F.A.P.; SOPOLLATTO, M. et al. Parâmetros de fermentação e medidas morfométricas dos compartimentos ruminais de bezerros leiteiros suplementados com milho processado (floculado vs. laminado a vapor) e monensina. Revista Brasileira de Zootecnia, v.32, n.4, p.1021-1031, 2003.

OLIVEIRA, V.C.; FONTES, C.A.A.; SIQUEIRA, J.G. et al. Produção de leite e desempenho dos bezerros de vacas Nelore e mestiças. Revista Brasileira de Zootecnia, v.36, n.6, p.2074-2081, 2007.

POPPI, D.P.; McLENNAN, S.R. Protein and energy utilization by ruminants at pasture. Journal of Animal Science, v.73, p.278-290, 1995.

RATKOWSKY, D.A. Nonlinear regression modeling: a unified practical approach (statistics: a series of textbooks and monographs, v.48). New York: Marcel Dekker Inc., 1983, 276p.

ROHWEDER, D.A.; BARNES, R.F.; JORGENSEN, N. Proposed grading standards based on laboratory analysis for evaluating quality. Journal of Animal Science, v.47, p.747-759, 1978.

ROSA, A.N. Manejo e melhoramento genético. CATTO, J.B.; SERENO, J.R.B.; COMASTRI FILHO, J.A. (Orgs.). Tecnologias e informações para a pecuária de corte no Pantanal. Corumbá: EMBRAPA-CPAP, 1997. p.85-111.

SANTOS, S.A.; COSTA, C.; SOUZA, G.S. et al. Qualidade da dieta selecionada por bovinos no Pantanal da sub-região da Nhecolândia. Revista Brasileira de Zootecnia, v.31, n.4, p.1663-1673, 2002.
SANTOS, S.A.; SOUZA, G.S.; ABREU, U.G.P. et al. Curva de crescimento de bezerros Pantaneiros, Nelore e Cruzas Nelore $\mathrm{x}$ Pantaneiro, Nelore x Caracu criados no Pantanal. In: SIMPÓSIO IBERO AMERICANO SOBRE CONSERVACIÓN Y UTILIZACIÓN De ReCursos ZOOgenéticos, 5., 2004. Puno, Peru. Memórias... Puno, 2004. p.45-47.

SANTOS, S. A.; ABREU, U. G. P. de.; COMASTRI FILHO, J.A. et al. Produção animal no bioma Pantanal: conservação e manejo sustentável dos recursos. In: REUNIÃO ANUAL DA SOCIEDADE BRASILEIRA DE ZOOTECNIA, 43., 2006, João Pessoa. Anais... João Pessoa: SBZ/UFPB, 2006. p.84-115.

SANTOS, S.A.; ABREU, U.G.P.; TOMICH, T. R. et al. Pecuária no Pantanal: em busca de sustentabilidade. In: ALBUQUERQUE, A.C.S.; SILVA, A.G. (Eds.). Agricultura tropical: quatro décadas de inovações tecnológicas, institucionais e políticas. Brasília: Embrapa Informação Tecnológica, 2008. p.535-570.

SANTOS, S.A.; ABREU, U.G.P.; SOUZA, G.S. et al. Condição corporal, variação de peso e desempenho reprodutivo de vacas de cria em pastagem nativa no Pantanal. Revista Brasileira de Zootecnia, v.38, n.2, p.354-360, 2009.

SOUZA, G.S. Introdução aos modelos de regressão linear. Brasília: Embrapa-SCT, 1998. 469p.

STATISTICAL ANALYSES SYSTEM - SAS. SAS/STAT user's guide: statistics. Version 9.1. Cary: SAS Institute, 2001. v.6., 2001. 943p.

TRENKLE, A.; MARPLE, D.N. Growth and development of meat animals. Journal of Animal Science, v.57, supl.2, p.273-283, 1983.

TULLIO, R.R.; ALMEIDA, I.L.; BRUM, P.A.R. Influência da idade de desmama sobre o desempenho reprodutivo de vacas de cria, no Pantanal Mato-Grossense. Corumbá: Embrapa-UEPAE de Corumbá, 1980. 3p. (Pesquisa em Andamento, 1).

VAN SOEST, P.J., ROBERTSON, J.B., LEWIS, B.A. Methods for dietary fiber, neutral detergent, and non-starch polysaccharides in relation to animal nutrition. Journal of Dairy Science, v.74, p.3583-3597, 1991. 